\title{
Naturalised species of Agave L. (Agavaceae) in the Eastern Cape Province of South Africa
}

\author{
Gideon F. Smith', Michele Walters ${ }^{2}$, Estrela Figueiredo ${ }^{3}$ and Ronell R. Klopper ${ }^{2}$ \\ ${ }^{1}$ Office of the Chief Director: Biosystematics Research and Biodiversity Collections and Acting Chief \\ Financial Officer, Private Bag X101, Pretoria, 0001 South Africa / John Acocks Chair, H.G.W.J. \\ Schweickerdt Herbarium, Department of Botany, University of Pretoria, Pretoria, 0002 South Africa \\ (email: smithg@sanbi.org). \\ ${ }^{2}$ Biosystematics Research \& Biodiversity Collections Division, South African National Biodiversity Institute, \\ Private Bag X101, Pretoria, 0001 South Africa (email: walters@sanbi.org; klopper@sanbi.org). \\ ${ }^{3}$ Herbarium, Instituto de Investigação Científica Tropical, Trav. Conde da Ribeira 9, 1300-142 Lisboa, \\ Portugal (email: estrelafigueiredo@hotmail.com).
}

Summary: In alpha-taxonomic terms the Eastern Cape Province of South Africa, which includes the entire Albany Centre of Endemism, is one of the richest succulent plant regions in the world. The mild climate of the region is also suitable for the cultivation of a number of exotic succulents, several of which have escaped into the natural flora, subsequently becoming naturalised. The five species of Agave L. recorded for the Eastern Cape are here described and illustrated as part of compiling a Flora for the region. The species are Agave angustifolia Haw. var. angustifolia, $A$. americana $L$. var. americana, $A$. sisalana Perrine, $A$. vivipara $L$. var. vivipara and A. wercklei F.A.C.Weber ex Wercklé. A key is provided to assist with the identification of the five species.

Zusammenfassung: In Bezug auf die alphaTaxonomie ist die Eastern Cape-Provinz der Republik Südafrika, die auch das gesamte Albany Centre of Endemism umfasst, eine der reichhaltigsten Sukkulentenregionen der Welt. Das milde Klima erlaubt auch die Kultur einer Reihe exotischer Sukkulenten, von welchen mehrere verwildert sind und sich in der natürlichen Flora etabliert haben. Die fünf für die Eastern Cape-Provinz nachgewiesenen Arten von Agave L. werden im Rahmen der Zusammenstellung einer Flora für das Gebiet beschrieben und abgebildet. Es handelt sich um die Arten Agave angustifolia Haw. var. angustifolia, $A$. americana L. var. americana, $A$. sisalana Perrine, $A$. vivipara L. var. vivipara und
A. wercklei F.A.C.Weber ex Wercklé. Als Hilfe bei der Identifikation der fünf Arten wird auch ein Schlüssel angeboten.

\section{Introduction}

South Africa has a remarkable diversity of plant life with more plant species occurring here than in any other region of similar size, making it the world's richest temperate country in terms of floral wealth (Cowling \& Hilton-Taylor, 1997). A large proportion of this floral wealth is made up of succulents, with an estimated $47 \%$ of the world's diversity occurring in southern Africa (Smith et al., 1997; Van Jaarsveld et al., 2000).

The Eastern Cape Province covers a total area of c. $170,000 \mathrm{~km}^{2}$ (Low \& Rebelo, 1996), is roughly situated between $30-34^{\circ} \mathrm{S}$ and $23-30^{\circ} \mathrm{E}$ and is topographically variable. Altitude ranges from sea level to about 2,000 $\mathrm{m}$ in the north-east and 2,100 $\mathrm{m}$ in the north-west (Smith \& Marx, 1990). Rainfall varies considerably in amount with rainfall decreasing from the coast inland and from east to west (Smith \& Marx, 1990). These variations in climatic variables contribute to supporting the diverse indigenous flora that is found in the region. The province has the most biomes and vegetation types (Low \& Rebelo, 1996) and supports vegetation ranging from indigenous sub-tropical forests to dry, subdesert karroid shrublands.

The Eastern Cape comprises 11 bioregions (Figure 2), being "composite spatial terrestrial units defined on the basis of similar biotic and physical features and processes at the regional 
scale" (Mucina \& Rutherford, 2006). These further support 93 vegetation types and the Maputaland-Pondoland-Albany hotspot (Steenkamp et al., 2004). The region also houses several important centres of plant diversity and endemism in South Africa (Van Wyk \& Smith, 2001). These are the Maputaland-Pondoland Region in which is nested the Pondoland Centre, the Drakensberg Alpine Centre, the Albany Centre and the eastern reaches of the Cape Floristic Region.

Succulents have adapted to occur across the region and are well represented throughout the bioregions and centres of endemism. The Pondoland Centre for instance houses more than 120 endemic/near endemic species of which $24.2 \%$ are succulents, while the Albany Centre is home to more than 600 endemic/near endemic taxa comprising $60.6 \%$ succulent species (Van Wyk \& Smith, 2001). The Drakensberg Alpine Centre in turn comprises more than 400 endemic/near-endemic taxa of which $5 \%$ is succulent (Van Wyk \& Smith, 2001).

The Agavaceae are a well known succulent plant family of the New World (Verhoek, 1998) with the genus Agave L. in particular being indigenous to Mexico, northern South America and the southern United States of America, as well as the West Indies. While no indigenous representatives in southern Africa exist, a number of species have become naturalised in the subcontinent (Smith et al., 1997).

As part of an ongoing project to compile a Flora for the Eastern Cape Province and to document alien invasive succulents in southern Africa, five species of Agavaceae were recorded as naturalised in the region. These five species, Agave americana L. var. americana, A. angustifolia Haw. var. angustifolia, $A$. sisalana Perrine, $A$. vivipara $\mathrm{L}$. var. vivipara and $A$. wercklei F.A.C.Weber ex Wercklé, are here described and a key provided to assist with the identification of the species. Distribution maps are provided for all species, based on recorded observations by the first author and on data from the Southern African Plant Invaders Atlas (SAPIA) database.

While the naturalised agaves are nowadays conspicuous elements where they occur in the Eastern Cape flora, none have reached the stage of being noxious weeds that threaten indigenous succulents. However, A. angustifolia in particular tends to locally form dense stands that virtually eliminate the movement of game and domestic stock.

\section{Agaves in the Eastern Cape}

Agave L. Common names: century plants; Afrikaans: garingbome. 5 species, Mexico.

Robust, monocarpic, usually rosulate perennials arising from short rhizome or short erect caudex. Stem commonly with monocotyledonous type secondary growth. Leaves usually crowded in basal rosette, leathery to succulent, amplexicaul, persisting for many years; each vascular bundle with well-developed fibrous cap at phloem pole. Inflorescence apical, tall, fast-growing, terminating in a panicle, often massive. Flowers bisexual, regular or somewhat irregular, tubular, pedicellate, trimerous throughout. Perianth petaloid, $3+3$, often fleshy, united below to form a tube. Stamens $3+3$; anthers mostly dorsifixed, introrse, versatile opening by longitudinal slits, linear to oblong. Ovary inferior, trilocular, with septal nectaries; placentation axile; ovules in 2 vertical rows in each locule; style terminal; stigma 3-lobed. Fruit a loculicidal capsule. Seeds many flattened, centrally embedded in copious, very hard endosperm. $x=30$.

For widely used synonyms of the naturalised species see Gentry (1982).

\section{A. Plants suckering from the base}

1. Agave americana L. var. americana (Figures 1 and 2)

Smith \& Mössmer, 1996. Bothalia 26: 31-35.

Medium-sized to large, acaulescent or shortstemmed, monocarpic, rosulate, perennial, leaf succulent; rosettes up to $2 \mathrm{~m}$ tall, profusely proliferous through basal suckers. Leaves light blue, erect at first, becoming spreading to reflexed, lanceolate, 1-2 m long; margins armed with numerous, straight to flexuous or variously recurved, simple teeth, up to $10 \mathrm{~mm}$ long; apical spine conical to subulate, $30-50 \mathrm{~mm}$ long. Inflorescence paniculate, 5-9 m tall, branched, never bulbiferous. Flowers erect, yellow to greenish yellow, 70-100 $\mathrm{mm}$ long. Stamens epipetalous; filaments $60-90 \mathrm{~mm}$ long; anthers yellow, 30-36 mm long, centric to excentric. Capsules oblong, 40-50 mm long. Seeds lunate to lacrimiform, 7-8 × 5-6 mm, shiny black. Flowering time Dec.-Feb.

\section{Agave angustifolia Haw. var. angustifolia} (Figures 3-5)

Steyn \& Smith, 2000. Bothalia 30: 43-55; as A. vivipara. 


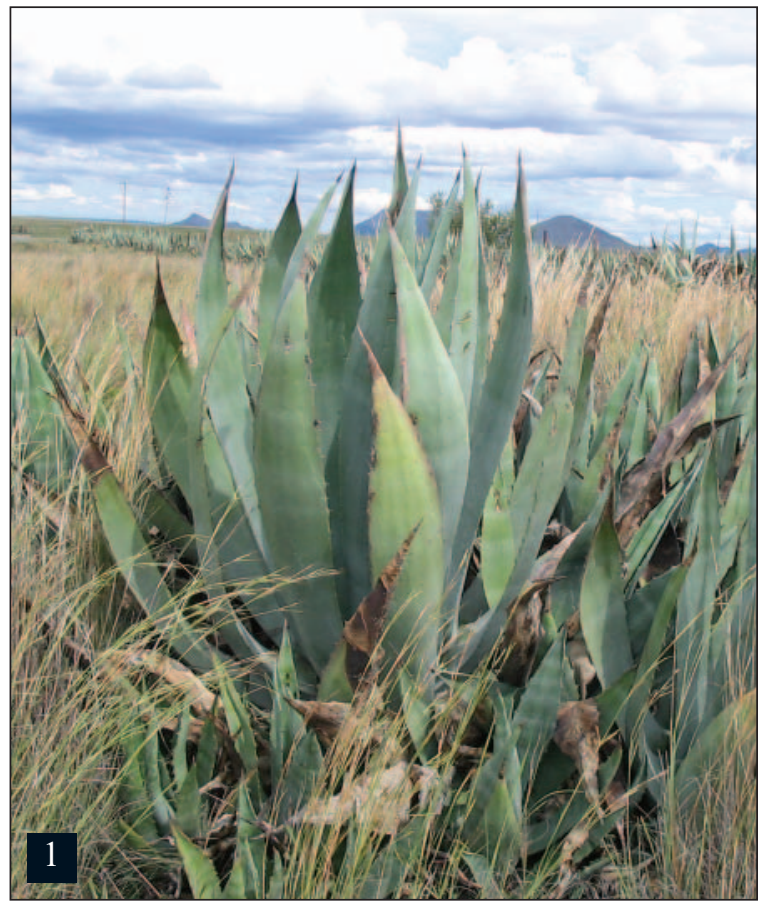

Medium-sized, caulescent, monocarpic, rosulate, perennial, leaf succulent; rosettes up to 1.2 $\mathrm{m}$ tall, proliferous through basal suckers. Leaves light green to glaucous grey, ascending to horizontal in mid-rosette, linear to narrowly lanceolate, 0.6-1.2 m long; margins armed with small teeth, curved or variously flexed, $2-5 \mathrm{~mm}$ long; apical spine conical to subulate; $15-35 \mathrm{~mm}$ long. Inflorescence paniculate, 3-5 m tall, branched, usually bulbiferous. Flowers erect, green to yellow, 50-65 mm long. Stamens epipetalous; filaments 35-45 mm long; anthers yellow, centric or excentric 20-30 mm long. Capsules ovoid, 30-50 mm long. Seeds D-shaped, $9-12 \times 7-8 \mathrm{~mm}$, dull black. Flowering time Feb.-Mar.

3. Agave sisalana Perrine (Figures 6 and 7) Smith \& Mössmer, 1996. Bothalia 26: 31-35.

Medium-sized to large, acaulescent or shortstemmed, monocarpic, rosulate, perennial, leaf succulent; rosettes up to $2 \mathrm{~m}$ tall; profusely proliferous through elongated rhizomes. Leaves dark green, erect throughout, lanceolate, 0.9-1.3 m long; margins lacking teeth; apical

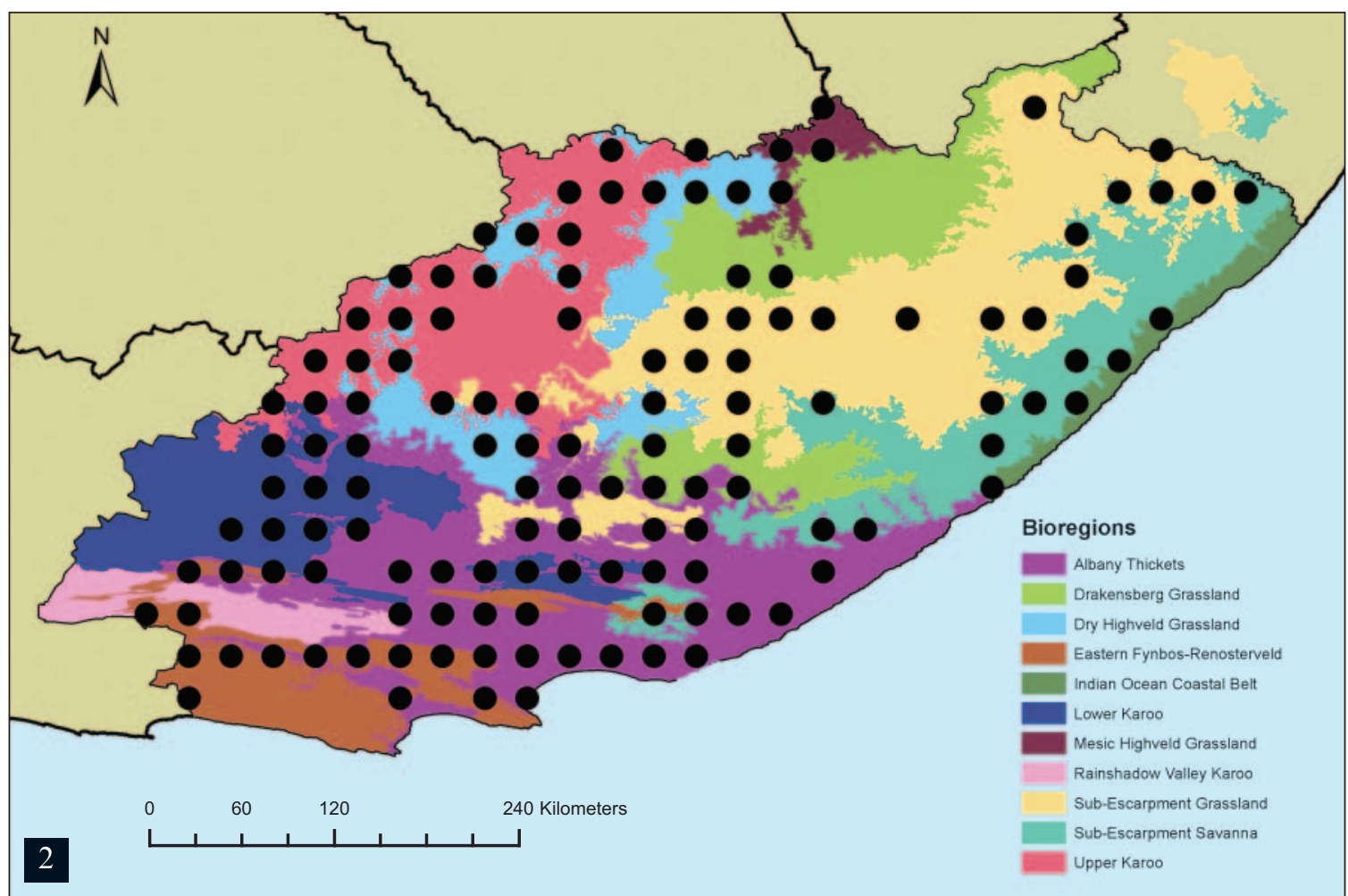

Figure 1. The leaves of $A$. americana var. americana have a distinctly bluish colour and their margins are armed with sharp teeth. The species is very proliferous through suckers. It is widely naturalised between Graaff-Reinet and Middelburg in the Eastern Cape, where this picture was taken. Photo: E. Figueiredo. Figure 2. Distribution (quarter degree squares) of $A$. americana var. americana in the Eastern Cape Province, South Africa. 

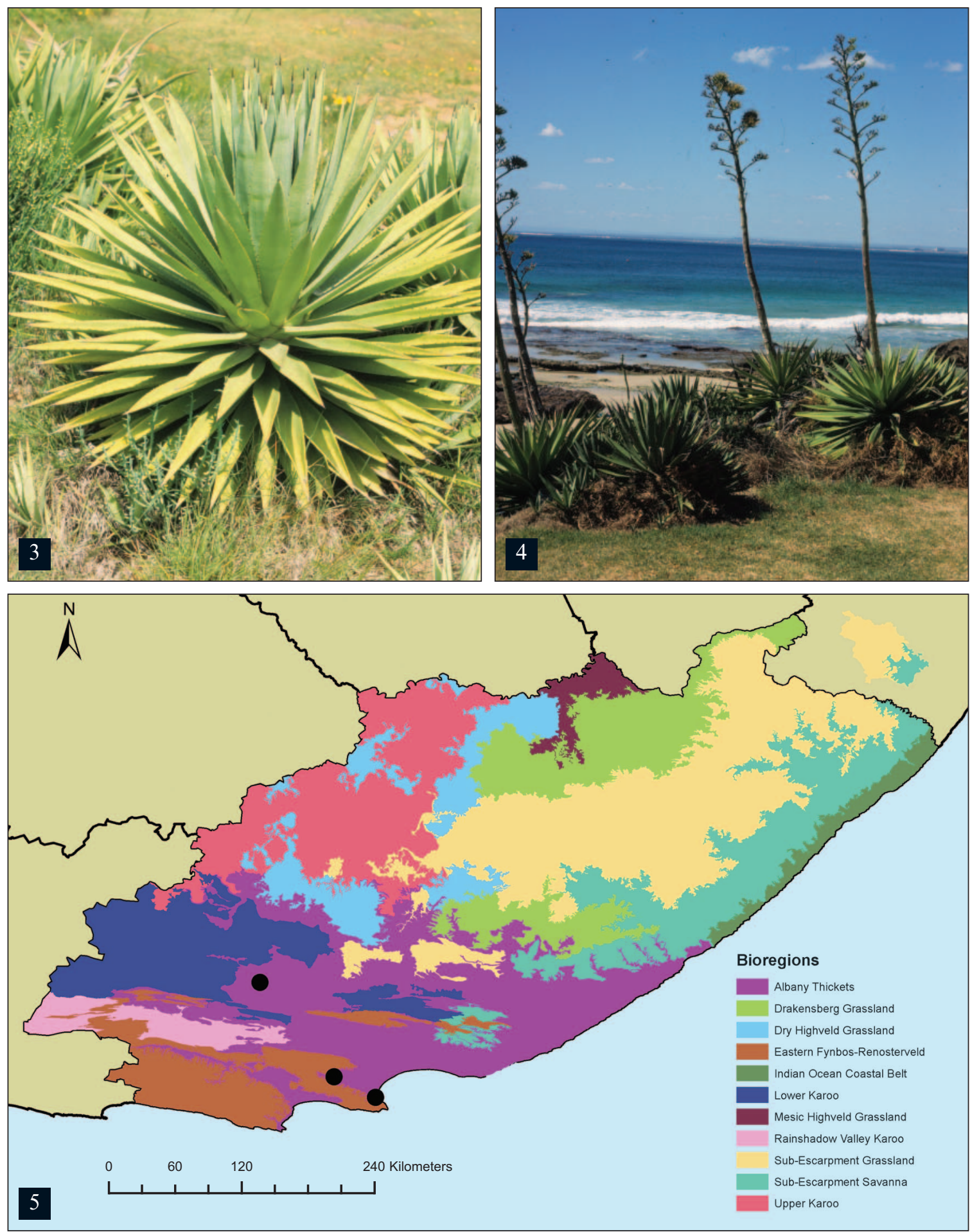

Figure 3. Close-up of a rosette of $A$. angustifolia var. angustifolia. The photograph was taken immediately north of Uitenhage, Eastern Cape. Photo: G.F. Smith. Figure 4. This clump of A. angustifolia var. angustifolia grows outside Port Elizabeth in the Eastern Cape. Photo: G.F. Smith. Figure 5. Distribution (quarter degree squares) of A. angustifolia var. angustifolia in the Eastern Cape Province, South Africa. 


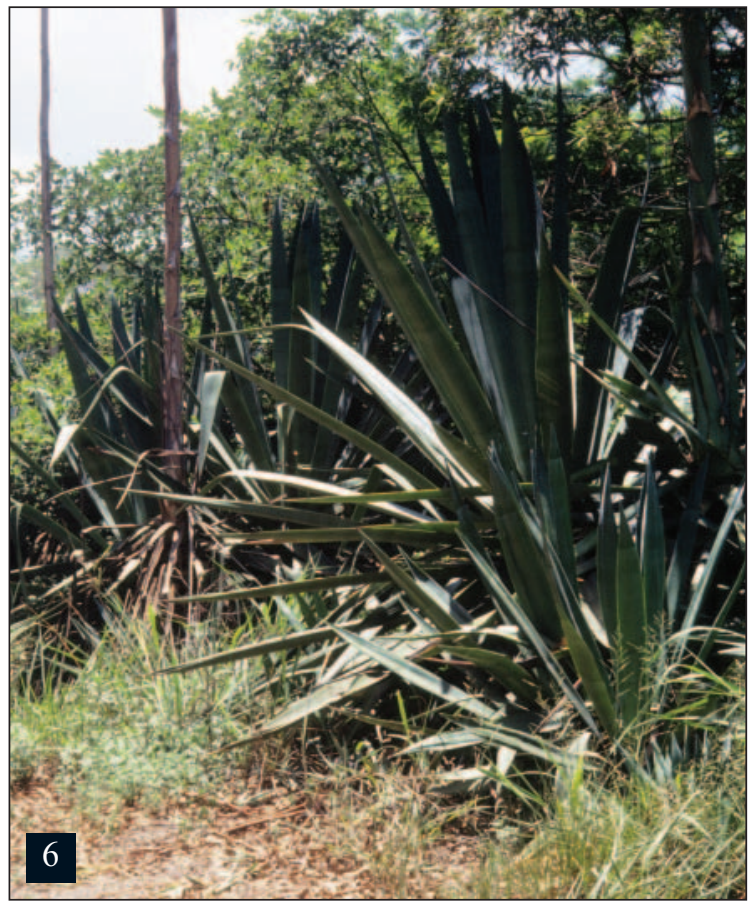

spine subulate, 20-25 mm long. Inflorescence paniculate, 4-9 m tall, branched, profusely bulbiferous. Flowers erect, greenish yellow, 55-65 $\mathrm{mm}$ long. Stamens epipetalous; filaments 50-60 $\mathrm{mm}$ long; anthers yellow, centric, 23-25 mm long. Capsules generally lacking; plants sterile. Seeds generally lacking. Flowering time unknown.

\section{Agave vivipara L. var. vivipara (Figures 8 and 9)}

Smith \& Steyn, 1999. S. Afr. J. Bot. 65: 249-252; as Agave decipiens.

Medium-sized, caulescent, monocarpic, rosulate, perennial, leaf succulent; rosettes up to 1.3 $\mathrm{m}$ tall; proliferous through subterranean stolons. Leaves dark green, rigidly spreading to recurving, narrowly lanceolate, $0.75-1 \mathrm{~m}$ long; margins armed with simple teeth, recurved, 1-2 mm long; apical spine conical, 10-15 $\mathrm{mm}$ long. Inflorescence paniculate, 6-7 $\mathrm{m}$ tall, branched, usually bulbiferous. Flowers erect, yellowish green, 50-55 mm long. Stamens epipetalous, filaments $45-48 \mathrm{~mm}$ long; anthers light green with brownish red speckles, excentric, $20 \mathrm{~mm}$ long.

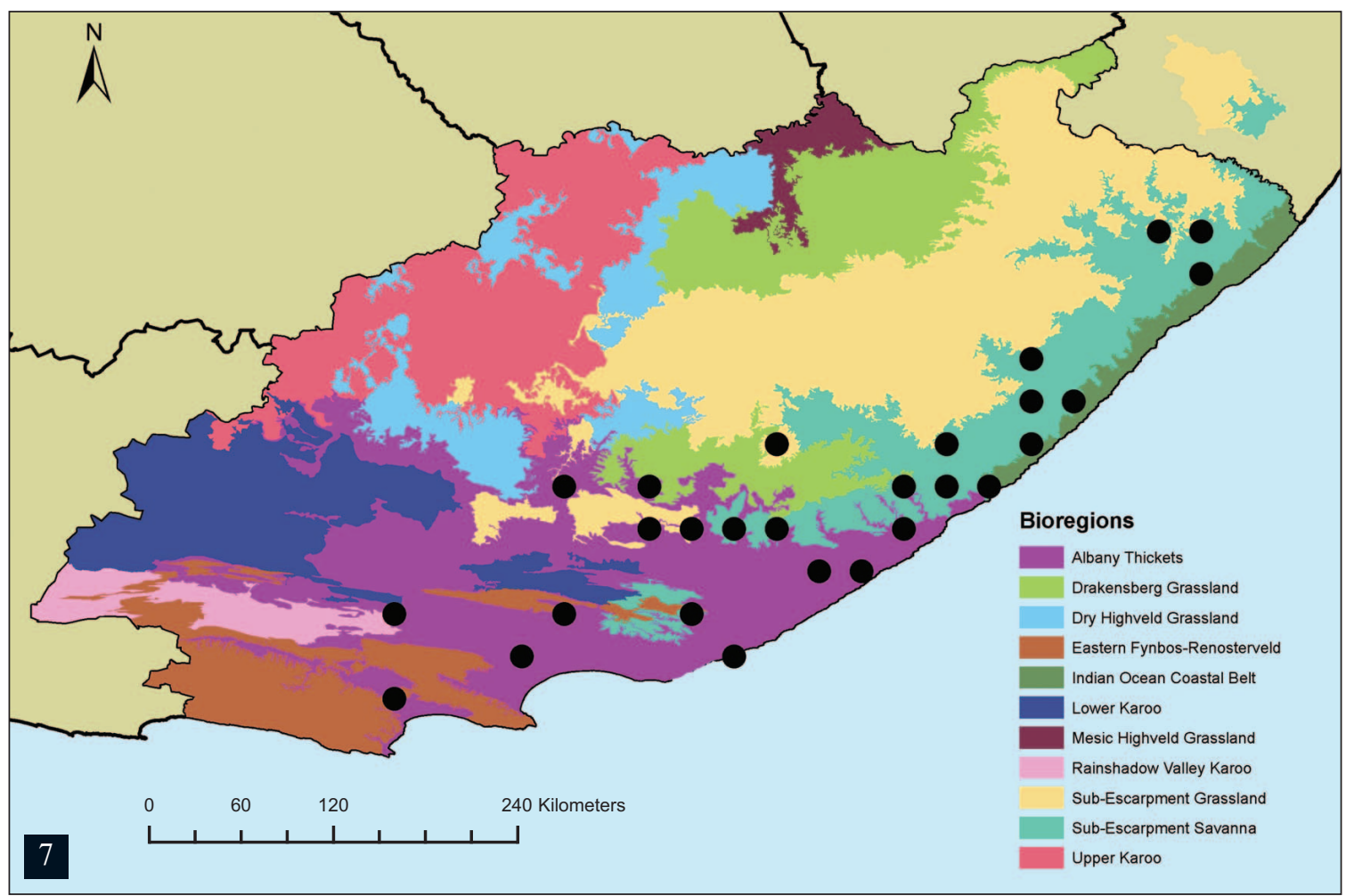

Figure 6. The dark green leaves of $A$. sisalana are generally spineless, but the tips are very sharp. In some of the subtropical areas of southern Africa the species is still cultivated for the strong fibres that can be extracted from its leaves. Photo: G.F. Smith. Figure 7. Distribution (quarter degree squares) of A. sisalana in the Eastern Cape Province, South Africa. 

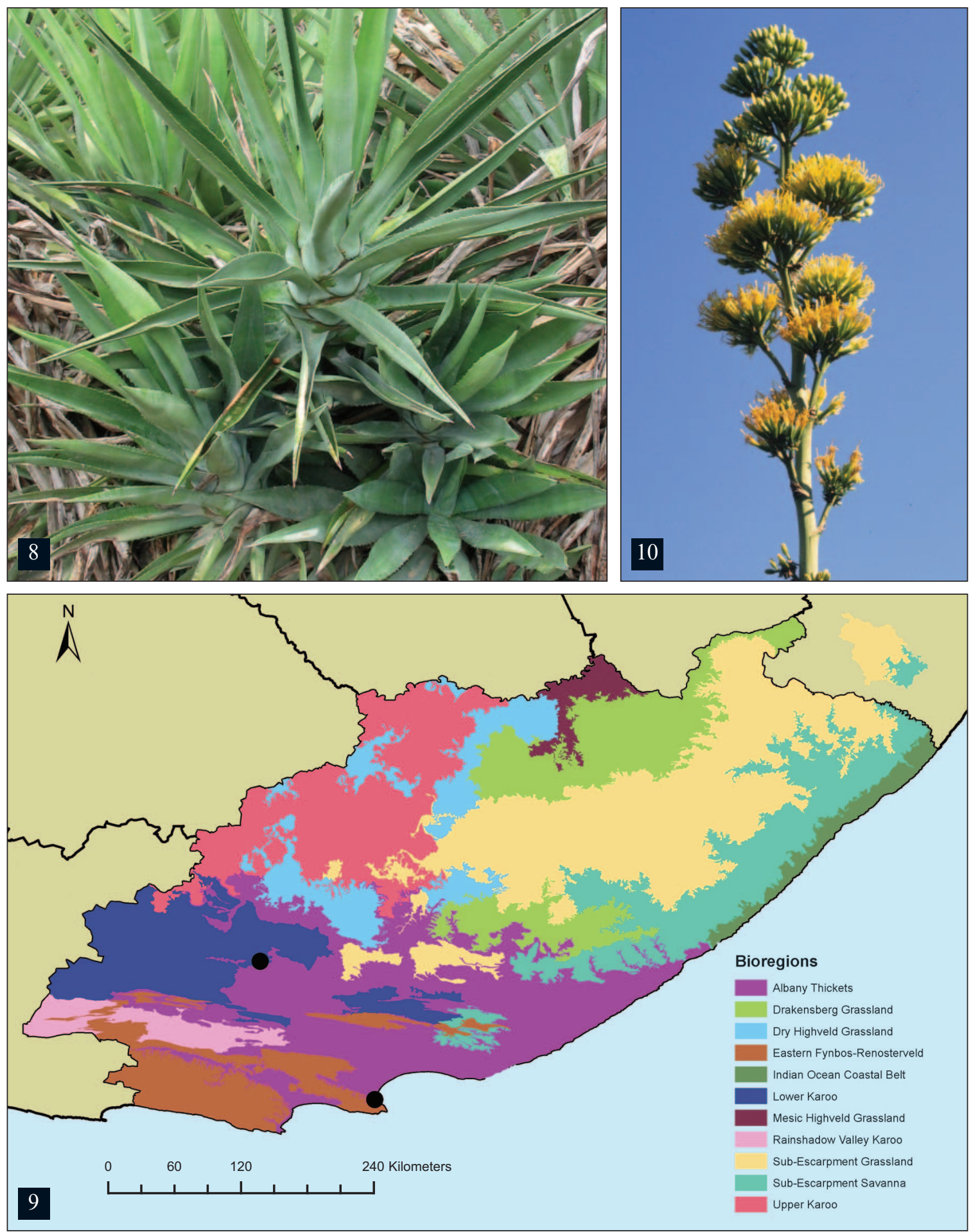

Figure 8. Close-up of the rosettes of A. vivipara var. vivipara showing the enlarged leaf bases. The photograph was taken in Jansenville in the Eastern Cape Karoo. Photo: E. Figueiredo. Figure 9. Distribution (quarter degree squares) of A. vivipara var. vivipara in the Eastern Cape Province, South Africa. Figure 10. Close-up of an inflorescence of $A$. wercklei. Photo: G.F Smith. 


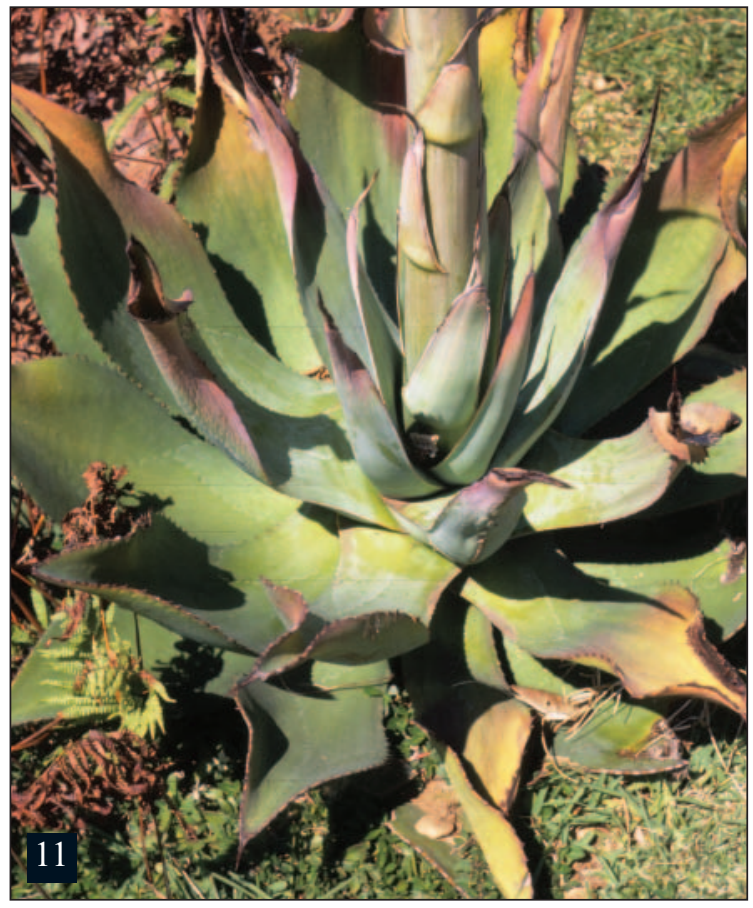

Capsules ellipsoid to oblong, 35-50 mm long. Seeds not seen. Flowering time variable, Jun.-Aug.

\section{B. Plants solitary}

5. Agave wercklei F.A.C.Weber ex Wercklé (Figures 10-12)

Smith \& Steyn, 2002. Bradleya 20: 45-50.

Medium-sized to large, acaulescent, monocarpic, rosulate, perennial, leaf succulent; rosettes up to $2 \mathrm{~m}$ tall, non-surculose. Leaves light glaucous green, often with whitish grey sheen, rigidly spreading, ovate to lanceolate, short-acuminate, 0.7-1.5 m long; margins armed with simple teeth, straight or variously recurved, 3-4 mm long; apical spine conical, 20-30 mm long. Inflorescence paniculate, $4-8 \mathrm{~m}$ tall, branched, profusely bulbiferous. Flowers erect, basal part light green, tepals golden yellow, up to $80 \mathrm{~mm}$ long. Stamens epipetalous; filaments 90 mm long; anthers golden yellow, $16 \mathrm{~mm}$ long. Capsules ovoid-angular, 22-30 × 15-18 mm. Seeds hemispherical, $5 \times 4 \mathrm{~mm}$, black. Flowering

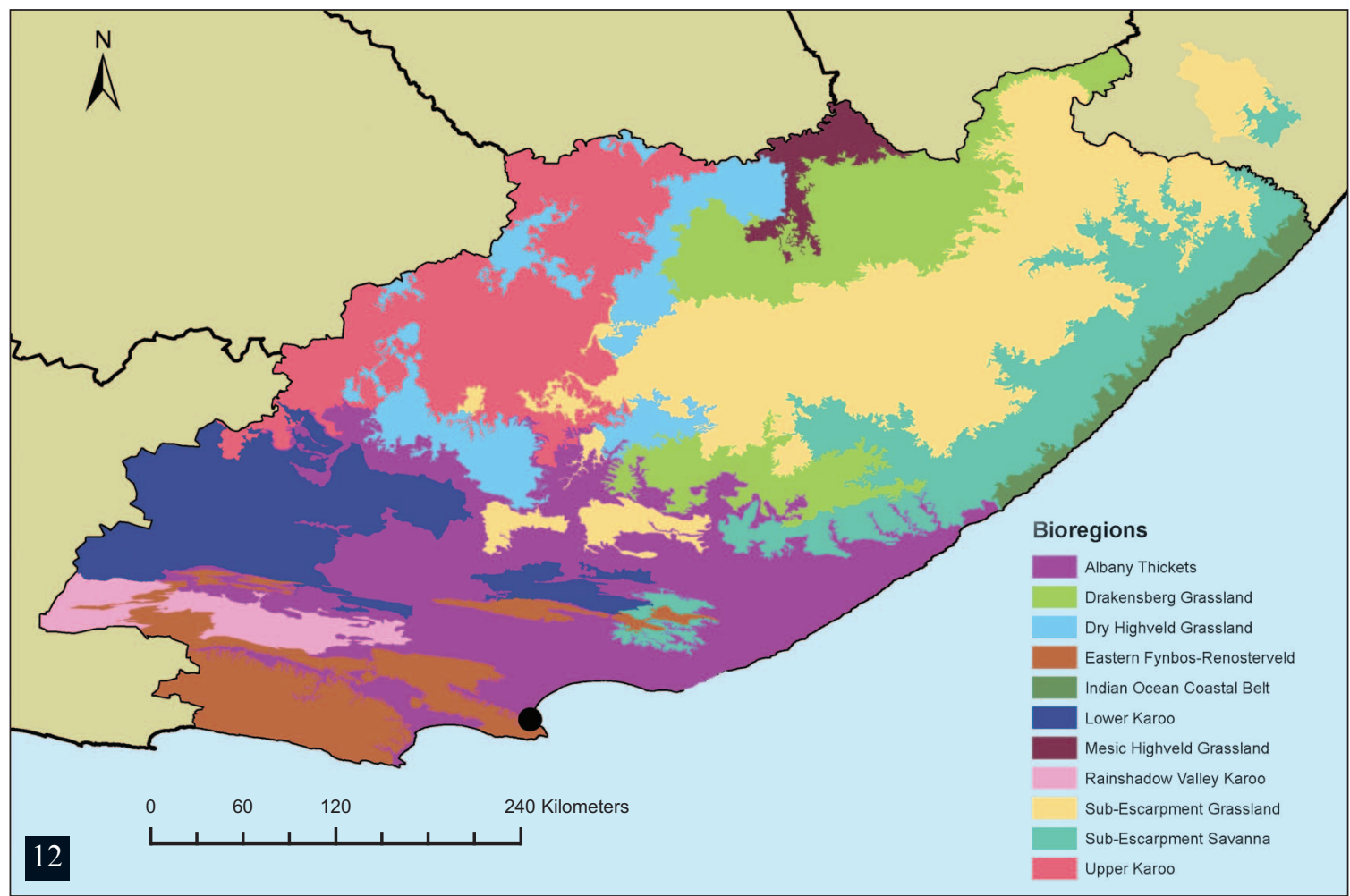

Figure 11. Close-up of a rosette of $A$. wercklei. The species has been located near the Baakens River Valley in Port Elizabeth. Photo: G.F. Smith. Figure 12. Distribution (quarter degree squares) of $A$. wercklei in the Eastern Cape Province, South Africa. 


\section{Key to the species of Agave naturalised in the Eastern Cape}

1. Leaf margins devoid of teeth A. sisalana

1'. Leaf margins armed with sharp teeth. 2

2. Leaves glaucous green to distinctly light blue, often drooping to one side; plants massive

A. americana var. americana

2'. Leaves light- to dark green, erect to stiffly spreading; plants medium-sized to large .3

3. Plants solitary A. wercklei

3'. Plants proliferous from the base

4. Leaves dull green, armed with short, brown teeth; mid-rosette leaves spreading, closely packed on stem .... A. angustifolia var. angustifolia

4'. Leaves dark green, armed with prominent, greenish brown teeth; mid-rosette leaves erect, widely spaced on stem A. vivipara var. vivipara

time Jan.-Mar.

It has been recorded from a single locality in the Baakens River Valley in Port Elizabeth.

\section{Acknowledgements}

Ms Lesley Henderson of the ARC-Plant Protection Research Institute is thanked for providing information from the Southern African Plant Invaders Atlas (SAPIA) database on the distribution ranges of the Eastern Cape agaves.

\section{References}

Cowling, R.M. \& Hilton-TaYlor, C. (1997). Phytogeography, flora and endemism. In R.M. Cowling, D.M. Richardson \& S.M. Pierce (eds.), Vegetation of southern Africa. Cambridge University Press, Cambridge.

GentRY, H.S. (1982). Agaves of continental North America. University of Arizona Press, Tucson.

JACOBSEn, H. (1960). A handbook of succulent plants. Descriptions, synonyms and cultural details for succulents other than Cactaceae. Vol. I. Blandford Press, London.

Low, A.B. \& ReBelo, A. (1996). Vegetation of South Africa, Lesotho and Swaziland. Department of Environmental Affairs and Tourism, Pretoria.

MucinA, L. \& Rutherford, M.C. (eds.) (2006). The vegetation of South Africa, Lesotho and Swaziland. Strelitzia 19. South African National Biodiversity Institute, Pretoria.

SMith, G.F. (2000). Agavaceae. In O.A. Leistner (ed.), Seed plants of southern Africa: families and genera. Strelitzia 10: 567. National Botanical Institute, Pretoria.

Smith, G.F. \& MARX, G. (1990). Notes on the veg- etation and succulent flora of the eastern Cape Province, South Africa. Aloe 27: 56-66.

Smith, G.F. \& Mössmer, M. (1996). FSA contributions 4: Agavaceae. Bothalia 26: 31-35.

SMith, G.F. \& STEYN, E.M.A. (1999). A first record of Agave decipiens naturalised in southern Africa. S. Afr. J. Bot. 65: 249-252.

Smith, G.F. \& SteYn, E.M.A. (2002). Agave wercklei: a mesoamerican species in South Africa. Bradleya 20: 45-50.

Smith, G.F., Van JaArsveld, E.J., Arnold, T.H., Steffens, F.E., Dixon, R.D. \& Retief, J.A. (1997). List of southern African succulent plants. Umdaus Press, Pretoria.

Steenkamp, Y., Van WyK, B., Victor, J., Hoare, D., Smith, G., Dold, T. \& Cowling, R. (2004). Maputaland-Pondoland-Albany. In R.A. Mittermeier, P.R. Gil, M. Hoffman, J. Pilgrim, T. Brooks, C.G. Mittermeier, J. Lamoreux \& G.A.B. Da Fonseca (eds.), Hotspots revisited. Cemex, Mexico City.

SteYn, E.M.A. \& SMITH, G.F. (2000). Agave vivipara: a naturalised alien in southern Africa. Bothalia 30: 43-55.

VAN JAARSVELD, E., VAN WyK, B-E. \& SMITH, G.F. (2000). Succulents of South Africa: a guide to the regional diversity. Tafelberg, Cape Town.

VAN WYK, A.E. \& SMITH, G.F. (2001). Regions of floristic endemism in southern Africa: a review with emphasis on succulents. Umdaus Press, Pretoria.

Verhoek, S. (1998). Agavaceae. In K. Kubitzki (ed.), The families and genera of vascular plants. Vol. 3: Flowering plants, Monocotyledons: Lilianae (except Orchidaceae). Pp. 60-70. Springer-Verlag, Hamburg. 